\title{
龍山火山周辺の湖沼について
}

(插図 $1 \sim 5$ )

\author{
加藤 武 雄 \\ On the lakes in the vicinity of the Ryuzzan Volcano \\ (Yamagata Prefecture) \\ By Takeo Katō
}

1.はしがき

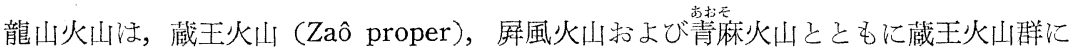
属する 1 火山である. かつて，これ注在の蔵王温泉地带を主に火山活動の中心とした。 この火山の基盤岩は花崗岩，第三系であり，これ它山山灰，火山磁，橄筧石複輝石安山 岩，集塊岩などが被うている(市村，1957）.

この火山の周辺には，多くの湖沼が分布しているが，地理的地質的にみると 3 群に分け られる。いま，こ机らの分布図定図1にかかげよう。さて，このうらの第I群はい和河る 神尾爆裂火口の押し出した泥流上に水空たた光るもので, 龍山火山の西方斜面に散在す る. 第 II 群は高湯爆裂火口底にある湖沼群で，第 III 群汹龍山火山之蔵王火山との中間地 域にある湖沼群である。こ狆らの湖沼は，いずれも受水面積せまく，注入河川の目立つも のも少ない. 夏季㧍よび秋季には，湖水位のいちじるしく低下するものもある.

これまで，これらの湖沼については，まとまつた報告はなされていない. 筆者は 1953〜 1955 年の間に，こ机らについて水質を中心にした調查を行なつたので，得られた成果を 報告したいと思う。

\section{2. 主な湖沼の湖盆形態}

筆者の調查した13の湖沼のうち，第I 群に属する代表的な湖沼 4 つについて湖盆形態の

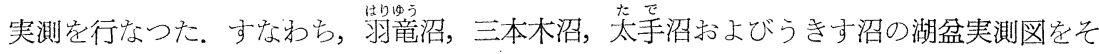
れぞれ，図 2，3，4，5にしめす。また，それぞれの湖沼について，図上り求めた計測 結果を表 1 にまとめておく.

この地域の湖沼では，羽竜沼が最も大きく，三本木沼がこれに次ぐ。その他の湖沼は， 大体太手沼程度である，さて，計測した湖沼の湖岸の形態をみると，太手沼が最も円形に 


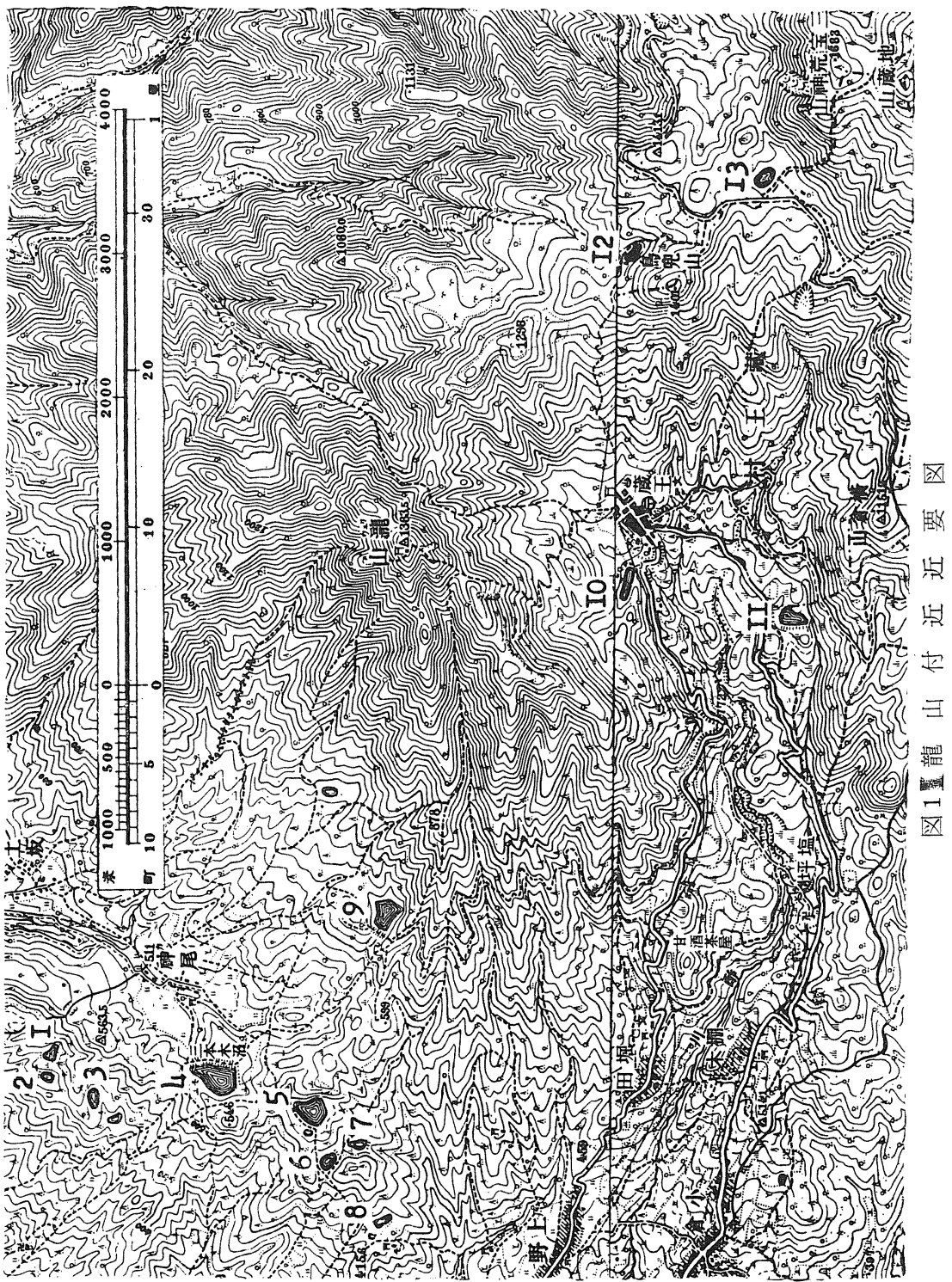




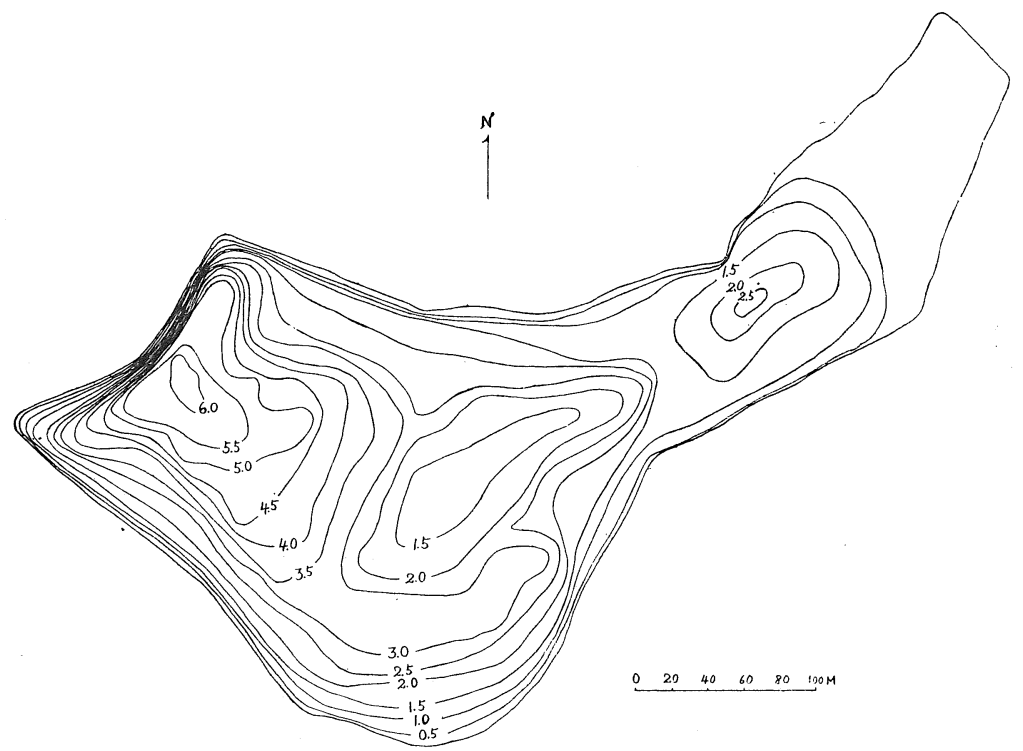

図2 羽龍琶沼

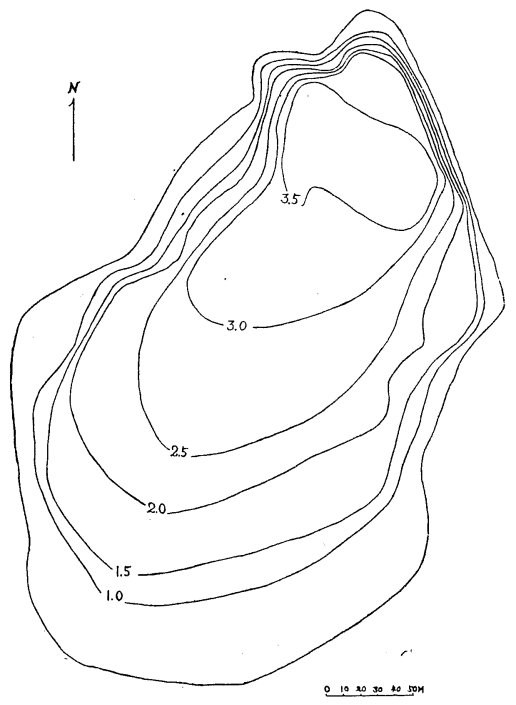

図3 三本木沼

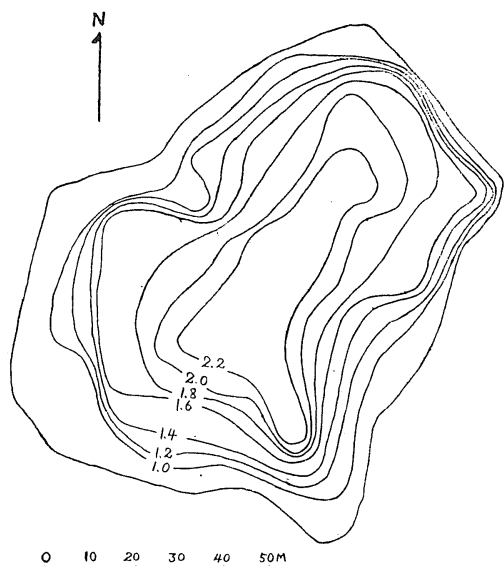

図4 太手沼 
表 1 . 湖 盈形態棓測 表

\begin{tabular}{|c|c|c|c|c|}
\hline 湖 沼 名 & 羽 竜 沼 & 三本朴沼 & 太手 沼 & うきす沼 \\
\hline 測 定 年 月 & 1953. V & 1953. V & 1953. V & 1955. IV \\
\hline 湖岸線の長さ (m) & 1560 & 1090 & 352 & 268 \\
\hline 湖表面積 $\left(\mathrm{m}^{2}\right)$ & $8.54 \times 10^{4}$ & $7.26 \times 10^{4}$ & $0.823 \times 10^{4}$ & $0.449 \times 10^{4}$ \\
\hline 積 $\left(\mathrm{m}^{3}\right)$ & 1. $73 \times 10^{5}$ & $1.23 \times 10^{5}$ & $0.943 \times 10^{4}$ & 1. $11 \times 10^{4}$ \\
\hline 量 & 1.50 & 1.14 & 1.09 & 1.13 \\
\hline 最大深度 (m) & 6.00 & 3.80 & 2.20 & 3.40 \\
\hline 平坞深度 (m) & 2.02 & 1.69 & 1.14 & 2.43 \\
\hline
\end{tabular}

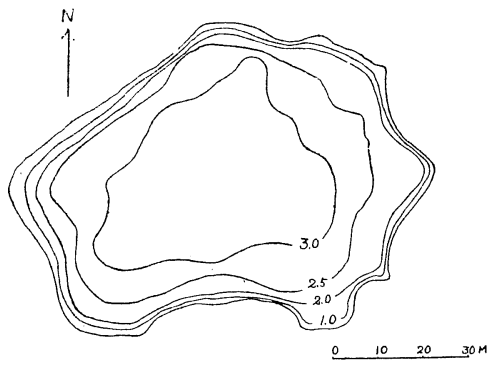

図 5 うきす沼
近いことがわかる。すなわち，肢節量がほぼ 1 に近い. 三本木沼，らきす沼も円形に近い方で ある. 羽竜沼の肢節量は 1.50 で, 形状は複雑 で北東部に突出した部分がみとめら㞦る。深度 は，いずれも浅く， $6.00 \mathrm{~m}$ が錘測にて得られ た最大值にすぎない，これらの湖沼は泥流の蕉 みに出来た湖だからであろう。残りの湖沼につ いての湖盈形態は，いずれ筆者らによつて明ら かにされるはずである。

\section{3. 湖水の化学的性質}

龍山周辺の湖水の化学的性質觉知るために，次のような化学分析を行なつた，その方法 老略記しよう。採水は，なるべく湖心部をえらび，深度約 $20 \mathrm{~cm}$ の水㟈試料とした。先 ず， $\mathrm{pH}$ は比色法，蒸発残渣，酸度，メチルオレンジルカリ度は常法によつた。溶存酸 素は WINKLER 法にしたがい，酸素飽和度は TrUESDALE 等の表（1955）在を用い，高度 補正安行なつて計算した。 また，化学的酸素消費量 (COD) は過マンガン酸カリウム法， 塩素イオンは MOHR 法, 硫酸イオンは重量法. 珪酸は DiÉNERT-WANDENBULKE の比出 法，酸可溶性鉄分の分析はチオシアン酸アンモニウムによる比色法を採用した。アルミニ ウムイオンは $\left(\mathrm{Fe}_{2} \mathrm{O}_{3}+\mathrm{Al}_{2} \mathrm{O}_{3}\right)$ 学もとめた值から鉄の部分を差引いて求めた值である。 た，カルシウムイオン注酸カルシウムとして沈搌字つくり，後に過マンガン酸カリウム で滴定したものである。マグネシウムイオンはオキシン法，マンガンイオンは過ヨウ素酸 カリウム学用いる比色法，カリウムイオンは過塩素酸法にしたがつた。ナトリウムイオン は $(\mathrm{NaCl}+\mathrm{KCl})$ 学測定した後に，カリウムイオンの分を差し引いて計算した。

いま，各湖沼の化学分析の結果を表 2 にしす。これには参考までに，蔵王火山の火口 
湖「お釜」の水質をも付記してある，次にこれらにもとずいて二，三の説明䘮試みよう。

筆者は，地形，地質的に龍山火山周辺の湖沼を 3 群にわけたが，表 2 からわかるように 水質からも，そのまま 3 群に分けてよいように思われる。いま，こう推定した理由や，各 群の特徴などを説明することにしよう。

第 I群は $\mathrm{pH}$ が 6.7 7.0 の中性の湖沼で, 蒸発残渣は $37 \sim 63 \mathrm{mg} / l$ の範囲内にある. 過マンガン酸カリウム消費量も割合に小さく, おおやつ沼の $21.6 \mathrm{mg} / l$ 定のぞけば, すべ て $10 \mathrm{mg} / l$ 以下である. 塩素イオン，硫酸イオン濃度も小さく，それぞれについて，たか だか $8.4 \mathrm{mg} / l ， 3.6 \mathrm{mg} / l$ しかふくまれない. その他，多くのカチオンについても濃度が 小で，とりたてて記すべきものがない．ただ，鉄分に $1.0 \mathrm{mg} / l$ をこえるものがあること だけである。こ机は試水を口過せずに，そのままの状態で塩酸を加えて化学分析をしてい るからであろう、いわゆる酸可溶性鉄分を測つたからである。マンガンイオンを，ほとん ぞふくまないことも，第I群の特徴といえる.

第 II 群に属するものには, 盃湖と鶇の谷地沼との二つがある. 弥発残渣はいずれも 100 $\mathrm{mg} / l$ 学越し，それぞれ $156 \mathrm{mg} / l ， 105 \mathrm{mg} / l$ である。他の 2 群のほぼ 2 倍の值宗示す. 硫酸イオンも含有量がいちじるしく大きく, 盃湖が $69.9 \mathrm{mg} / l$, 鴫の谷地沼が $28.7 \mathrm{mg} / l$ である，塩素イオンも，両者が $35 \mathrm{mg} / l$ 程度の值を示す．過マンガン酸カリウム消費量が $30 \mathrm{mg} / l$ を越し，カルシウムイオン濃度がほぼ $10 \mathrm{mg} / l$ かとれ机上であり，他の 2 群に比 ベていちじるしく大きい.この上，特記すべきことの一つは，マンガンイオンが第 II 群 にふくなれることである。盃湖, 鵬の谷地沼が, それぞれ $0.84 \mathrm{mg} / l, 0.44 \mathrm{mg} / l$ の濃度 をしめす。

このように第II 群は，一般に溶存北登成分の濃度が他の 2 群に比べて大きい。 この理 由としては，これらの湖沼が高湯爆裂火口内にあり，乙かも蔵王温泉（硫化水素含有強酸 性緑樊明樊泉）に近い位置にあるからだと考えてよい. このような条件が湖水の水質に大 きい影響を与えていることは疑い得ない事実である。夺，鴫の谷地沼については，さらに 祐川が注いでいることも見のがしてはならないであろう。これは，筆者の調查（1958）に よれば $\mathrm{pH}=4.9$ の河川で，塩素イオン $4.5 \mathrm{mg} / l$, 硫酸イオン $25 \mathrm{mg} / l$, カルシウムイオ $27.35 \mathrm{mg} / l$, 酸可溶性鉄分 $0.23 \mathrm{mg} / l$ なる分析值军与光る. これらの諸数值と，表 2 中 の鴫の谷地沼の分析值とが，ほぼ類似していることは，祓川が湖水に大きく影響をおよぼ していることを物語るものである.

おわりに第 III 群について説明を行なおう. $\mathrm{pH}$ は 7 に近く, 蒸発残渣も $40 \mathrm{mg} / l$ 前後で 第I群と似ておる。ただ第I 群と異なることは，過マンガン酸カリウム消費量が $30 \mathrm{mg} / l$ 台で大きく，硫酸イオン濃度が $5 \mathrm{mg} / l$ 程度でやや大であり，ナトリウムイオンを約 $8 \mathrm{mg} / l$ ふくさことである。この群は第 II 群と異なり，いわゆる火山活動の影響という ものは考光られない，地質環境からみても第I群と似ており水質も割合に類似している。 
表 2 湖 沼 9 水質 分

\begin{tabular}{|c|c|c|c|c|c|c|}
\hline 湖沼番号（湖沼群） & $1(\mathrm{I})$ & $2(\mathrm{I})$ & $3(\mathrm{I})$ & $4(\mathrm{I})$ & $5(1)$ & $6(\mathrm{I})$ \\
\hline $\begin{array}{ccc}\text { 湖 沼 } & \text { 名 } \\
\text { 採 水 } \text { 日 時 }\end{array}$ & $\left|\begin{array}{c}\text { うきす沼 } \\
\mathrm{IV-29,} \\
11^{n} .25^{m}\end{array}\right|$ & $\left|\begin{array}{c}\text { 太手 沼 } \\
\text { IV-29, } \\
10.20\end{array}\right|$ & $\left|\begin{array}{c}\text { おおやつ沼 } \\
\text { VII-20, } \\
15.15\end{array}\right|$ & $\begin{array}{l}\text { 三本木沼 } \\
\text { VII-2, } \\
09.25\end{array}$ & $\left|\begin{array}{c}\text { 㿼沼 } \\
\text { VII-20, } \\
13.10\end{array}\right|$ & $\left|\begin{array}{ll}\text { な } & \text { 乙 } \\
\mathrm{V}-30, & \\
& 11.40\end{array}\right|$ \\
\hline 気 温 $\left({ }^{\circ} \mathrm{C}\right)$ & 15.6 & 15.0 & 30.0 & 27.0 & 29.2 & 22.1 \\
\hline 水 温 $\left({ }^{\circ} \mathrm{C}\right)$ & 15.8 & 15.8 & 34.0 & 24.2 & 30.0 & 18.1 \\
\hline $\mathrm{pH}$ & 6.7 & 6.7 & 6.7 & 6.9 & 7.1 & 6.7 \\
\hline 度 $(\mathrm{me} / \mathrm{l})$ & 0.063 & 0.067 & 0.022 & 0.042 & 0.015 & - \\
\hline M.O.アルカリ度(" & 0.38 & 0.34 & 0.23 & 0.22 & 0.20 & - \\
\hline 溶存酸素 $(\mathrm{mg} / \mathrm{l})$ & 4.48 & 4.65 & 5.78 & 6.66 & 6.08 & 4.33 \\
\hline 酸素飽和度* $(\%)$ & 49.3 & 51.1 & 85.7 & 86.4 & 85.7 & 50.3 \\
\hline 蒸発残渣 $(\mathrm{mg} / \mathrm{l})$ & 53 & 41 & 63 & 37 & 52 & 54 \\
\hline $\mathrm{COD}\left(\mathrm{O}_{2} \mathrm{mg} / \mathrm{l}\right)$ & 1.4 & 1.3 & 5.47 & 2.2 & 1.48 & 1.0 \\
\hline $\begin{array}{l}\mathrm{KMnO}_{4} \text { 消費量 } \\
(\mathrm{mg} / \mathrm{l})\end{array}$ & 5.4 & 5.1 & 21.6 & 8.8 & 5.85 & 4.1 \\
\hline$(11)$ & 8.4 & 5.9 & 4.9 & 4.6 & 4.3 & 4.8 \\
\hline $\mathrm{SO}_{4}{ }^{2-}$ & 3.2 & 3.6 & 0.2 & 2.1 & 0.2 & 0.45 \\
\hline (11) & 7.00 & 6.68 & 2.27 & 3.95 & 4.43 & 5.43 \\
\hline $\mathrm{Fe}^{2+}+\mathrm{Fe}^{3+}(11)$ & 1.1 & 1.38 & 0.72 & 0.11 & 0.30 & 0.24 \\
\hline $\mathrm{Al}^{3+}$ & 0.0 & 0.6 & 1.0 & 0.73 & 1.1 & 4.1 \\
\hline (11) & 3.5 & 2.4 & 1.1 & 0.18 & 2.33 & 2.1 \\
\hline $\mathrm{Mg}^{2+}$ & 2.4 & 0.64 & 0.22 & 1.3 & 0.16 & 0.33 \\
\hline $\mathrm{Mn}^{2+}$ & 0.0 & trace & trace & 0.0 & trace & 0.0 \\
\hline $\mathrm{Na}^{+}$ & 6.8 & 0.8 & 2.3 & 2.2 & 1.6 & 1.5 \\
\hline (II) & 0.4 & 0.1 & 0.3 & 0.1 & 0.2 & 0.2 \\
\hline 高 $(\mathrm{m})$ & 440 & 430 & 440 & 520 & 460 & 500 \\
\hline
\end{tabular}

* 高度補正を行なつた飽和度をしめす。

\section{4. むすび}

龍山火山周辺の湖沼群について，水質および湖盈形態を研究して，その結果を報告し た．水質地質両面から，こ机らの湖沼は 3 群に分類されることを知つた。 そのうち，高湯 爆裂火口内にある湖沼群は硫酸イオンに富み，蔵王温泉の影響がみとめられた。なお，湖 盈形態は主なもの 4 つついて計測を行ない，円形に近い形態が多いことを知つた。

この研究をなすに当り, 佐藤次男, 福田昌夫および石沢好雄三君の協力を得た。記して 謝意を表する。 
1961]

析 表（龍山火山周辺）－1955-

\begin{tabular}{|c|c|c|c|c|c|c|c|}
\hline 7 (I) & $8(\mathrm{I})$ & $9(\mathrm{I})$ & 10 (II) & 11 (II) & 12 (III) & 13 (III) & 14 (IV) \\
\hline $\begin{array}{c}\text { な } \\
\text { V-30, } \\
\\
\quad 11.25\end{array}$ & $\mid$\begin{tabular}{c|} 
な \\
VII-20, \\
$\quad 11.30$
\end{tabular} & $\mid \begin{array}{c}\text { 羽 龍 沼 } \\
\text { VII-2, } \\
07.50\end{array}$ & $\begin{array}{l}\text { 盃 湖 } \\
\text { IX-11, } \\
12.00\end{array}$ & $\begin{array}{l}\text { 鴫の谷地沼 } \\
\mathrm{IX}-11, \\
10.10\end{array}$ & $\begin{array}{c}\text { ドッコ沼 } \\
\text { IX-11, } \\
09.30\end{array}$ & $\begin{array}{c}\text { 片貝 沼 } \\
\mathrm{IX}-11, \\
08.40\end{array}$ & $\begin{array}{l}\text { お 釜 } \\
\text { VIII-6, } \\
09.45\end{array}$ \\
\hline 22.2 & 29.8 & 24.7 & 19.3 & 15.8 & 9.9 & 8.7 & 21.2 \\
\hline 18.0 & 30.5 & 22.8 & 19.8 & 16.0 & 9.0 & 13.2 & 19.3 \\
\hline 6.8 & 6.9 & 7.0 & 6.9 & 5.8 & 6.9 & 6.7 & 2.9 \\
\hline- & 0.032 & 0.048 & 0.030 & 0.086 & 0.030 & 0.030 & 4.3 \\
\hline - & 0.24 & 0.24 & 0.33 & 0.10 & 0.33 & 0.22 & - \\
\hline 5.67 & 7,00 & 7.13 & 6.28 & 9.09 & 8.08 & 7.64 & 7. 08 \\
\hline 65.7 & 99.1 & 91.9 & 77.6 & 103 & 84.4 & 88.8 & 96.0 \\
\hline 53 & 55 & 38 & 156 & 105 & 45 & 40 & 1043 \\
\hline 0.30 & 1.75 & 2.2 & 9.29 & 8.49 & 8.49 & 9.52 & - \\
\hline 1.2 & 6.92 & 8.8 & 36.7 & 33.5 & 33.5 & 37.6 & - \\
\hline 6.2 & 4.8 & 3.3 & 4.8 & 4.9 & 3.1 & 3.6 & 8.3 \\
\hline 0.0 & 1.0 & 3.5 & 69.9 & 28.7 & 4.5 & 5.1 & 498 \\
\hline 6.82 & 9.41 & 4.06 & 6.93 & 3.90 & 9.65 & 2.70 & 76.2 \\
\hline 0.13 & 0.65 & 0.081 & 0.71 & 0.26 & 0.063 & 0.096 & 32.5 \\
\hline 3.6 & 0.60 & 0.53 & 6.1 & 2.1 & 0.70 & 2.1 & 54.3 \\
\hline 2.4 & 0.68 & 0.14 & 21.4 & 9.38 & 4.30 & 2.65 & 65.4 \\
\hline 1.5 & 0.32 & 1.2 & 3.39 & 1.14 & 0.15 & 0.20 & 5.78 \\
\hline 0.0 & trace & trace & 0.84 & 0.44 & 0.0 & 0.0 & 0.23 \\
\hline 1.8 & 0.5 & 1.4 & 11.8 & 4.4 & 8.0 & 8.2 & 18 \\
\hline 0.1 & 0.3 & 0.4 & 0.4 & 0.9 & 0.4 & 1.4 & 0.6 \\
\hline 480 & 480 & 650 & 740 & 680 & 1260 & 1360 & 1560 \\
\hline
\end{tabular}

参考 文 献

市村 毅: Geological Investigations on the Zaō Volcanoes. IV Ryūzan Volcano.

Bull. Earthq. Res. Inst., 35, 573 593, 1957.

加藤武雄 : 須川水系の陸水学的研究報告. 山形市, 1958.

Truesdale, G.A., Downing, A.L. and Lowden, G.F. : The solubility of oxygen in pure water and sea-water. J. appl. Chem., 5, 53 63, 1955. 


\section{S U M M A R Y}

The Ryūzan Volcano is one of the famous volcanoes of the Zaō volcanic group. The surrounding area of this volcano is characterized by the abundance of lakes. Considering from the geological and geochemical points of view, these lakes are classified into the following three groups.

The 1st Group: This group consists of several lakes in the area covered by Kannō mud flow which extends at the western side of the Ryūzan Volcano. These lakes are represented by Haryū-numa, Sanbongi-numa, Sara-numa, Tade-numa and others. The water of this group shows neutral reaction respectively, that is, the $\mathrm{pH}$ values lie between 6.7 and 7.0.

The 2nd Group: Two lakes, i.e. Sakazuki-ko and Shiginoyachi-numa, belong to this group. They are found at the bottom of the Takayu explosion crater. Having contaminated by the Zaō hot spring which gushes out here and there in the same explosion crater, they are rich in dissolved substances, and in particular the concentrations of $\mathrm{SO}_{4}{ }^{2-}, \mathrm{Cl}^{-}$and $\mathrm{Mn}^{2+}$ are much higher than those of the 1st and the 3rd group. Moreover, it is needless to say that the chemical quality of Shiginoyachi-numa is influenced by the acidic river, the Harai-gawa, that joins to this swamp.

The 3rd Group: This group consists of two lakes, i.e. Dokko-numa and Katakai-numa. These are found in the area enclosed by the Ryuzan Volcano and the Zaō Proper. The water of the lakes shows neutral reaction.

(著者: 加藤武雄, 山形大学教育学部化学教室, 山形市; Takeo $\mathrm{K}_{\mathrm{AT}}$; ; Institute of Chemistry, Faculty of Education, Yamagata University, Yamagata) 